\title{
An Action Research Methodology into the Interpretation on Withholding Tax: In the Case of the Inland Revenue Board of Malaysia
}

\author{
Hazlina Hussain ${ }^{* 1}$ and Nor Aziah Abd. Manaf ${ }^{2}$ \\ ${ }^{1}$ Inland Revenue Board of Malaysia \\ 2 Tunku Puteri Intan Safinaz School of Accountancy, Universiti Utara Malaysia, Malaysia
}

\begin{abstract}
This paper describes the research work undertaken by the authors in applying action research methodology to identify the interpretation spectrum of the withholding tax provision in respect of section 4A of the Income Tax Act 1967 and the related public ruling. There has been no similar study published on using action research to improve the clarity of withholding tax provision. This study discusses the interpretation spectrum of section 4A of the Act on withholding tax. It is essential to focus on tax clarity as tax uncertainty affect both taxpayers and tax administration. The research had adopted action research method and utilised qualitative method of data gathering by way of focus group and semi-structured interviews and concludes that section 4A need improvements and policymakers should focus their attention on enacting clear law so that taxpayers understand and comply with the law.
\end{abstract}

Keywords: Action Research, Interpretation, Tax clarity, Tax Certainty

JEL Classification: $\mathrm{H} 2, \mathrm{H} 29$, B4

Paper Type: Research

\section{INTRODUCTION}

The focus of the research begins from the researchers growing concern on the interpretation spectrum of section 4A of the Income Tax Act $1967^{1}$ (ITA) and the related

\footnotetext{
* Corresponding author: E-mail: hazlinahussain@hasil.gov.my

${ }^{1}$ Section 4A of the Income Tax Act is a special classes of income provision which empowers the Director General of Inland Revenue to tax non-resident on income which is deemed to be derived from Malaysia.
} 
public ruling ${ }^{2}$. This is evident from conflicting interpretations by the courts on the interpretation of withholding tax provision under section 4A of the ITA as well as interpretation given by taxpayers from that of the Inland Revenue Board of Malaysia which can be seen from the appeal filed by taxpayers in respect of that issue.

Section 4A of the ITA (1983) is a special provision, and it was introduced to assess non-resident taxpayer by way of withholding tax, even though the non-resident taxpayer has no physical business presence in Malaysia. The policy to tax non-resident arises as a result of a court decision ${ }^{3}$ against the Inland Revenue Board Department ${ }^{4}$. The court decided that the management fee paid to Euromedical Industries Limited (EIL) which was incorporated in the United Kingdom and had no permanent establishment ${ }^{5}$ in Malaysia did not fall within the definition of "royalty" under the Double Taxation Agreement (DTA) between the Government of Malaysia and the United Kingdom. As such, Malaysia had no legal basis for taxing the fee received by EIL from Malaysia. The court further held that if there is a conflict of interpretation between the ITA and the DTA, the DTA should prevail. Thus, Malaysia can only tax EIL if EIL had a business income derived from a permanent establishment in Malaysia. The decision in Euromedical case had given a significant impact to the Government of Malaysia to tax non-resident if the non-resident does not have a permanent establishment in Malaysia.

Before the decision in Euromedical case and the insertion of section 4A into the ITA, the definition of "royalty" under the ITA includes payment for services. Hence, section 4A was introduced in 1983 to circumvent the problem concerning the interpretation of withholding tax on payment for services to non-resident, which is deemed to be derived in Malaysia. Thus, section 4A was introduced from the aftermath of the decision in Euromedical case.

Thus, the objective of introducing section 4A of the ITA is to ensure that any income which falls under section 4A of the ITA is subject to withholding the tax even though a nonresident has no permanent establishment in Malaysia. Consequently, Article 13 on "Fees for Technical services" was introduced into the Malaysian Double Tax treaties so that it is in line with the new section 4A of the ITA.

However, since it was introduced more than thirty years ago, the problem on the interpretation of section $4 \mathrm{~A}$ is still unsettled and controversial especially if the issue involves the interpretation of the Double Taxation Agreement ${ }^{6}$ entered into by the Government of Malaysia with countries outside Malaysia. The implications are verifiable from appeals filed by taxpayers and decisions of the court which had been decided in favour of taxpayers.

The issue of taxing non-resident about services has become an international issue as well. The United Nation (UN) has announced the new treaty and commentary update of the United Nation's 2011 model tax treaty, reflecting changes approved in April 2017 by the UN Committee of Experts on International Cooperation in Tax Matters (Multinational tax and transfer pricing news, 2018). One of the significant changes on the Model is on the incorporation of the new Article 12A on services. With the introduction of the new

\footnotetext{
${ }^{2}$ Public ruling no. 1/2004 was the first public ruling issued by the Inland Revenue Board of Malaysia on the application of withholding tax for special classes of income. It is issued by the Director's General based on his power under section 138A of the Income Tax Act 1967. Recently, the Public ruling no. 1/2004 is replaced by the Public Ruling No. 11/2018 which was published on 5 December 2018.

${ }^{3}$ Director General of Inland Revenue vs Euromedical Industries Ltd [1983] 2 MLJ 57

${ }^{4}$ Inland Revenue Department was a Government department before it became a statutory body and known as the Inland Revenue Board of Malaysia by virtue of the Inland Revenue Board of Malaysia Act 1995 [Act 533].

${ }^{5}$ Generally, a non-resident is considered as having a permanent establishment if it has a fixed place of business where the business is wholly or partly carried on in Malaysia.

${ }^{6}$ Double Taxation Agreement is an agreement entered into between the Government of Malaysia and another Government outside Malaysia which aims at avoiding a double taxation and prevention of fiscal evasion in repsect of taxes on income.
} 
Article, generally, a non-resident is subject to tax on any service of a managerial, technical or consultancy services (Falcao \& Michel, 2018).

Researchers generally conceded that the ITA is indeed a complicated law. A study was conducted to examine the complexity of the Malaysian Income Tax system by using $\mathrm{FRES}^{7}$ and $\mathrm{F}-\mathrm{KGL}^{8}$ systems on the ITA and the Schedules to the ITA through the readability perspective. It is found that the level of readability is low, and the materials can only be understood by those who studied at undergraduate and postgraduate level (Saad, Udin, \& Derashid, 2014). Thus, the tax authority must focus on drafting clear law so that the ITA is easily understood and the ramification, if the law is not complied with, is very well accepted by those who are affected by the law. This is also to avoid any loopholes that will give advantage to taxpayers not to comply with the law. With tax certainty, it will increase investment and trade in the country. Thus, the researchers seek to solve the problem of the interpretation of section 4A. Therefore, the research is about taking action through the research to solve the problem on the interpretation of section 4A of the ITA. Consequently, with clear law, this will improve the practices of the Inland Revenue Board of Malaysia as significant change or significant improvement on the provision of the law and ruling will improve compliance of the ITA.

\section{ACTION RESEARCH}

Several kinds of literature suggest that the origin of action research as being in the work of Kurt Lewin. He was known as the father of action research in which he developed a theory of action research that made it an acceptable form of research in social sciences (Herr \& Anderson, 2014). The term action research is also known by other terminologies such as participatory research, collaborative inquiry, emancipatory research, and action learning. Gilmore, Krantz, \& Ramirez (1986) defined action research as:

"Action research ... aims to contribute both to the practical concerns of people in an immediate problematic situation and to further the goals of social science simultaneously. Thus, there is a dual commitment to action research to study a system and concurrently to collaborate with members of the system in changing it in what is together regarded as a desirable direction. Accomplishing this twin goal requires the active collaboration of researcher and client, and thus, it stresses the importance of co-learning as a primary aspect of the research process."

The main distinction of action research from other types of research is that it emphasises on a scientific study where the researcher participated in the research and studied the problem systematically and much of the researcher's time is spent on refining methodological tools to suit the needs of the situation. Thus, action research is done by collecting, analysing, and presenting data on an ongoing cyclical basis (O'Brien, 1998). In other words, action research is taking action to improve practices. It is an interactive inquiry process that balances problem-solving actions implemented in a collaborative context with data-driven collaborative analysis or research to understand underlying causes enabling future predictions about personal and organisational change (McNiff, 2014).

\footnotetext{
${ }^{7}$ FRES measures the readability of technical writing, rates texts on a 100-point scale.

${ }^{8} \mathrm{~F}-\mathrm{GKL}$ translates the $0-100$ raw FRES into a school grade level.
} 


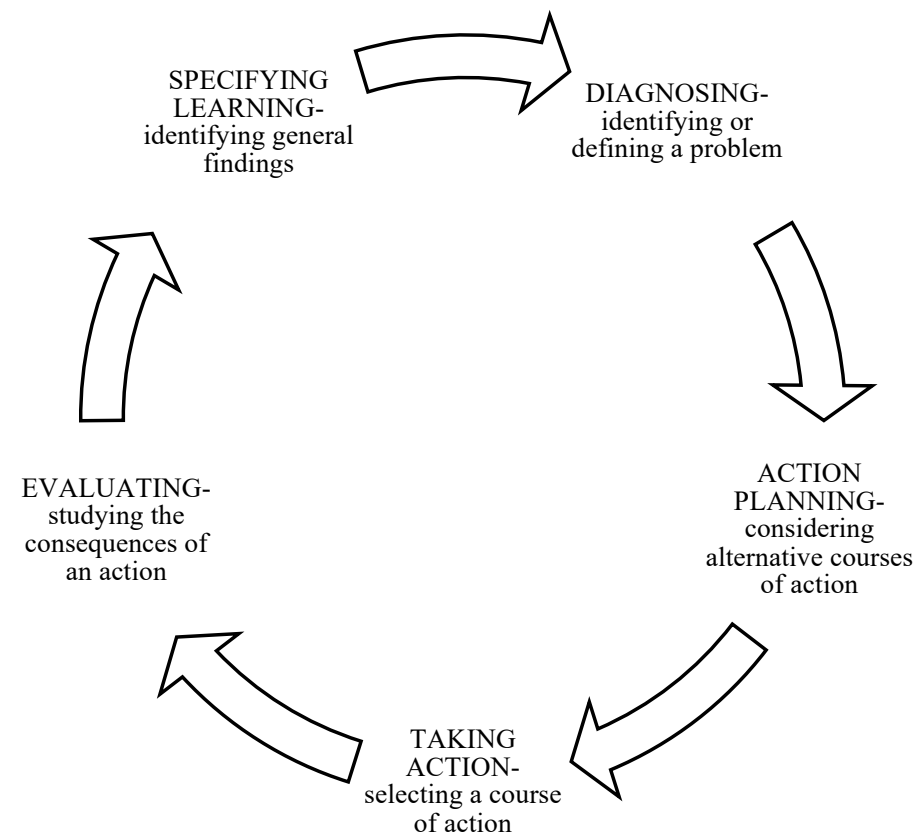

Figure 1. Detailed Action Research Model Source: Adapted from Susman (1983)

According to O'Brien (1998), one of the prominent advocates on action research is Gerald Susman, where he differentiated five cycles to be conducted in action research as in Figure 1. Firstly, a problem is identified, and data is collected for diagnosis. This is followed by a collective deduction of several possible resolutions, from which a single plan of action develops and is employed. Data on the results of the intervention are collected and analysed, and the findings are interpreted in light of how positive the action has been. At this point, the problem is re-examined, and the process begins another cycle. This process continues until the problem is solved. It is an action-oriented process (Selener, 1993). When action research is adopted, it has the potential to increase the amount of knowledge the researcher learned from the experience.

While based on Mcleod (2013), he had provided the most recent review on action research where Kolb's experiential learning style theory was adopted. Based on Kolb's theory, learning involves the acquisition of abstract concepts that can be applied flexibly in a range of situations. Effective learning is seen when a person progresses through a cycle of four stages: of (1) having a concrete experience followed by (2) observation of and reflection on that experience which leads to (3) the formation of abstract concepts (analysis) and generalizations (conclusions) which are then (4) used to test hypothesis in future situations, resulting in new experiences. As such, the action research cycle can also be regarded as a learning cycle.

According to Zuber-Skerritt and Perry (2002), action research is suitable for postgraduate research work. Azman (2014) had successfully demonstrated the use of action research in his postgraduate thesis. Subsequently, Mee and Hilman (2015) had also applied action research methodology in developing a framework for identifying unnecessary regulatory burdens on business.

\section{ACTION RESEARCH MODEL}

The researcher's proposed Action Research Model is, as shown in Figure 2. The 
researcher started with the action research cycle one, on the literature view based on the problem statements and research questions.

This is followed by several primary action research cycles carried out during the research. The researcher conducted an action research cycle two by way of a focus group discussion with nine participants. The participants were the legal and assessment officers from the IRBM as well as tax lawyers and tax agents from the private sectors so that the researchers could collect the data from the participants. The identification and careful selection of the participants were made based on each participant's experience and professional disciplines. This is to tap the participants experience in the subject matter of the discussion and therefore could give insights into the possible misinterpretation on the withholding tax provision of section 4A of the ITA. Demographic factors of the focus group participants include age, occupation, experience on the subject matter of the research, and qualification are considered. The researcher will moderate the discussion. The proposed questionnaires during the focus group include the following areas:

a) Understanding of section 4 A of the ITA

b) Whether there is a need to amend section 4A of the ITA

c) Whether section 4A of the ITA should be removed

The outcome which is expected from this focus group would be the general understanding of the interpretation of section 4A of the ITA from the perspectives of the IRBM and private sectors. 


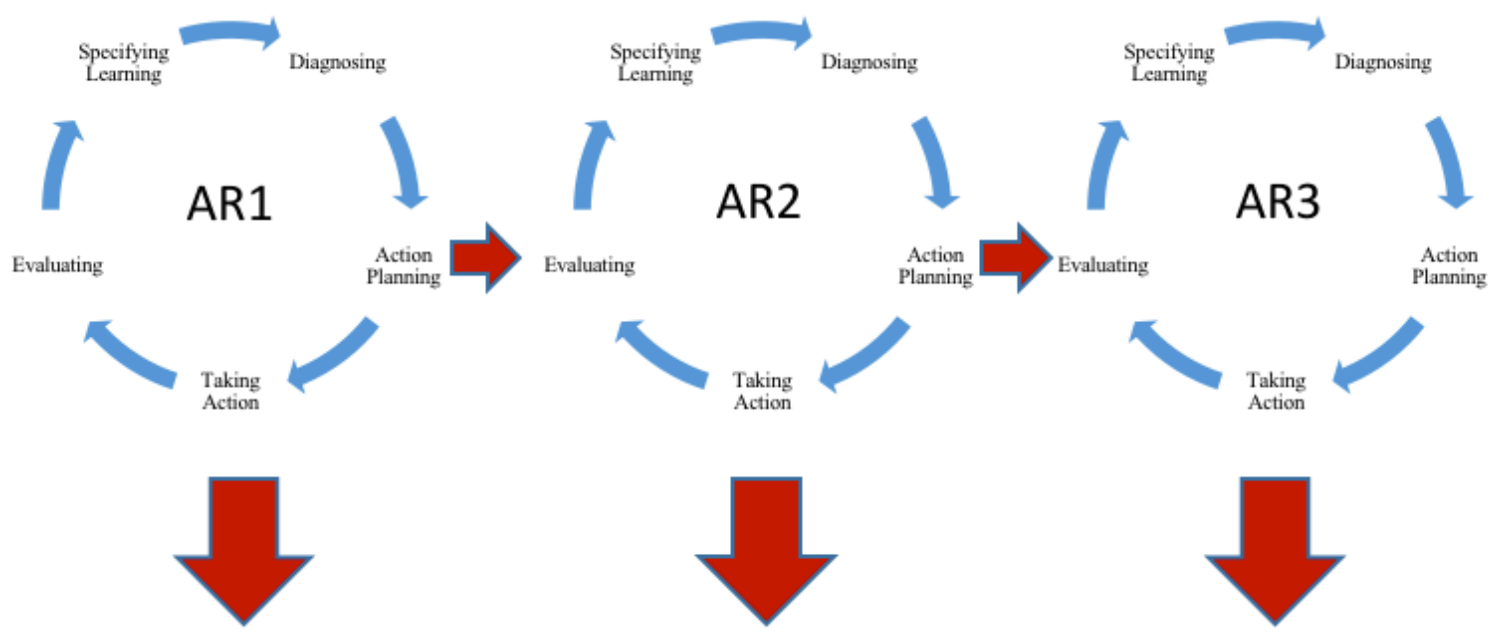

\section{- Literature review \\ - To identify the problem or redefine the problem.}

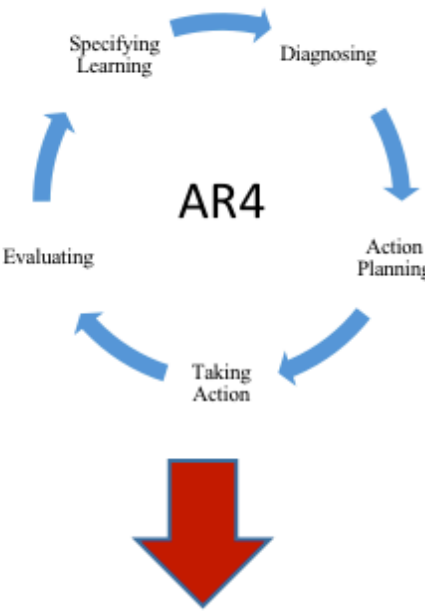

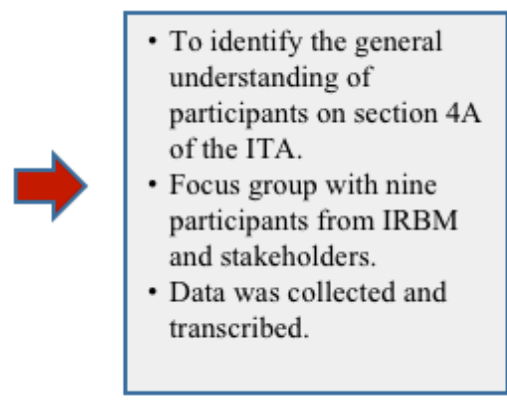

- To identify the general understanding of participants on section $4 \mathrm{~A}$ of the ITA.

Focus group with nine participants from IRBM

Data was collected and

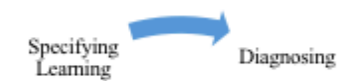

AR5
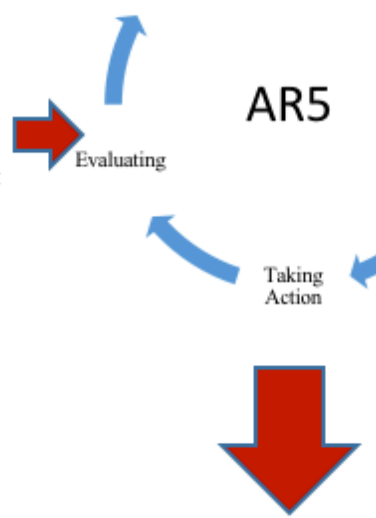

- To improve the draft of the proposed amendment to section $4 \mathrm{~A}$ of the ITA.

- To conduct a semistructured interviews with a Court of Appeal Judge and Dr. Arjunan Subramaniam.

- To improve the first draft

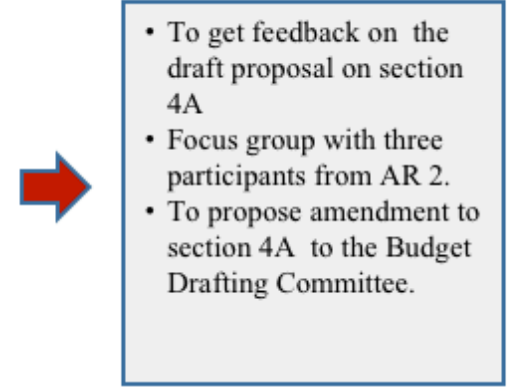

- To discuss with the expert.

- Focus group with three participants from the IRBM Non-Resident Branch and stakeholders.

- To prepare the draft amendment to section 4A of the ITA.

Figure 2. Proposed action research 
Once the general understanding of the participants on section $4 \mathrm{~A}$ and the public ruling is gathered, general knowledge on the problem is formed, and the researchers conducted the action research cycle three by way of the focus group. The third focus group was an in-depth discussion which involved the experts on the subject matter of research. Three new participants from the IRBM's Non-resident Branch, a private lawyer, and a tax agent were invited. The outcome of this discussion was a detail discussion on the areas and implementation of the law. The researchers had also conducted the action research cycle four, where semi-structured interviews with a Court of Appeal Judge and a renowned tax practitioner were done. Based on the knowledge formed during the focus groups and semistructured interviews in the action research cycles, the researchers had carefully articulated the problem and analysed the data. A draft on section 4A of the ITA was drafted based on the data collected from previous discussions. Subsequently, the researcher conducted the action research cycle five by inviting three participants from the action research cycle two, to test the improved draft of section 4A. The final action research cycle six was the redrafting of section 4A based on the feedback from the action research cycle five before the draft is approved by the Ministry of Finance for policy decision and tabled in the Parliament during the Budget 2019 (Finance Bill, 2018).

The qualitative data collected through focus group and the semi-structured interviews were transcribed and followed with the analysis. The transcript-based analysis represents the most rigorous and time-intensive mode of analysing data (Onwuegbuzie, Dickinson, Leech, \& Zoran, 2009). The researchers had adopted the micro-interlocutor analysis in their focus group data analysis where the focus group is used as a group analysis which excludes the analysis of individual focus group analysis. Thus, any participants in the group who did not contribute to the group discussion, such as, participant who is shy to speak, a participant who does not want to give any opinion are not acknowledged in the analysis. As noted by Nordness (2003), the agreement reached among the participants is the reflection and indication of the group dynamics.

\section{ACTION RESEARCH FINDINGS}

\subsection{Action Research Cycle 1}

The first action research cycle by the researchers is the literature review. The research was done based on Figure 1 with diagnosing, action planning, action taking, evaluation, and specifying learning. The critical finding by the researchers is that there is no previous research done on identifying the interpretation spectrum of the law by way of action research methodology.

\subsection{Action Research Cycle 2}

Data was gathered from the second action research cycle. The second action research cycle was conducted by way of a focus group of nine participants, and it addresses the first research question as follows:

"What are the understanding of taxpayers on section 4A and the public ruling?"

The researchers were surprised to find that almost all the participants agreed that section 4A of the ITA and the public ruling are challenging to understand, and they are not clear. The drafting of the law is not clear. It seems to be somewhat confusing and difficult to understand. The finding from the action research cycle forms the general knowledge on the main problem of the research. 
Table 1. Summary findings of the participants on the interpretation of section 4A and the public ruling

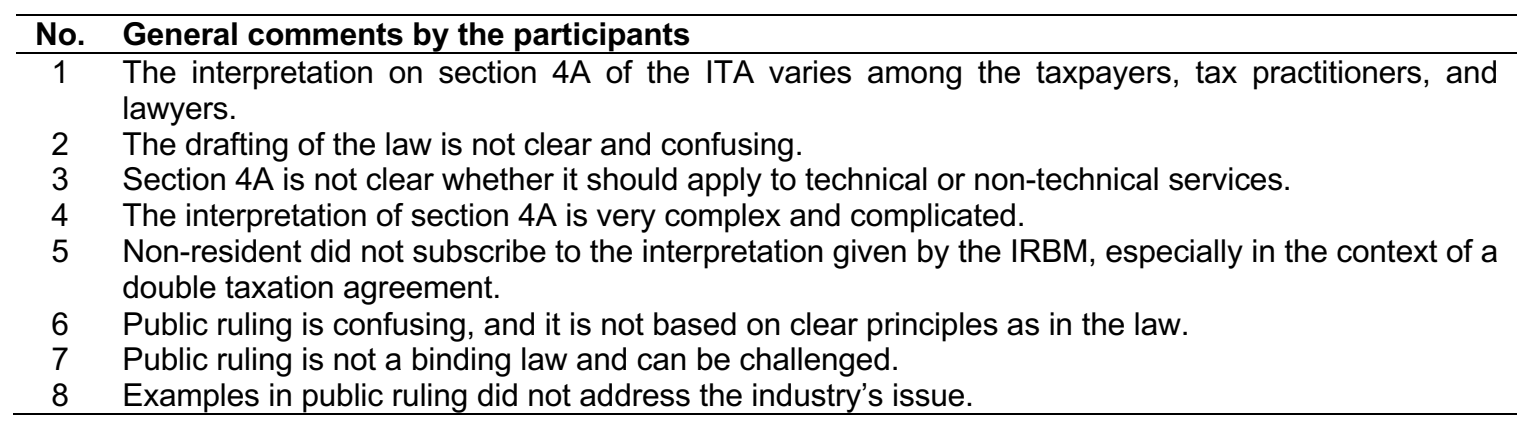

\subsection{Action Research Cycle 3}

The third action research cycle was conducted with a focus group of three participants. The participants were not from the second action research cycle. Hence three new participants were selected. The participants were directly involved in the application on withholding tax in their day-to-day work. The participants were from LHDNM's NonResident Branch, a private lawyer, and a tax agent. Thus, the action research cycle three was conducted to gauge in detail the interpretation of section $4 \mathrm{~A}$ and its impact on the Malaysia international double taxation treaties or agreements. The branch director of the Inland Revenue Board of Malaysia, as identified as one of the participants in this focus group commented as follows:

"We need to formulate clear cut principles underlying the taxation on withholding tax."

The other two participants were clearly in agreement with the first participant. They have suggested that if section 4A meant to tax technical as well as non-technical services, it has to be explicitly drafted in the law. According to one of the participants in this focus group, the public is still making inquiries on the correct interpretation and application of section 4A despite that the law was introduced more than thirty years ago, and the Inland Revenue Board had issued public ruling on section 4A of the ITA to deliberate on the application of section 4A. The objective for which the law was introduced in 1983 is still not clear. There is a gap in section $4 \mathrm{~A}$ which needs intervention. The participants suggested changes to the law as the priority in addressing the problem on the interpretation of section 4A. Based on this action research cycle, the researchers had explicitly identified the area of law which must be reviewed in the next action research cycle.

\subsection{Action Research Cycle 4}

The fourth action research cycle was conducted by way of semi-structured interviews with a court of appeal judge who wanted to remain anonymous and a renowned prominent tax practitioner who wrote an article (Subramaniam, 2014) after the Federal Court decision ${ }^{9}$ on section 4A which was decided in favour of the Inland Revenue Board of Malaysia. From these semi-structured interviews, the finding by the researcher is that generally all

\footnotetext{
${ }^{9}$ Inland Revenue Board of Malaysia vs Alam Maritim Sdn Bhd [2014] 3 MLJ vii.
} 
participants from the Inland Revenue Board of Malaysia, tax practitioner, industry player, judiciary and lawyers agree that section 4A needs to be improved and amended.

\subsection{Action Research Cycle 5}

Based on the knowledge from the four action research cycles, the researchers formulated a draft law in respect of Section 4A, which was given to the three participants from the second action research for comments. Only two participants responded and commented on the draft.

\subsection{Action Research Cycle 6}

Based on the input from the action research cycles, the researcher had redrafted section 4A after taking into account the comments made by the participants in the action research cycle five.

\section{CONCLUSIONS}

Action research is an effective research methodology in carrying out $\mathrm{PhD}$ research. It is more appropriate if the research's outcome is about to make changes to an organisation, and in this research, the organisation refers to the Inland Revenue Board of Malaysia. In essence, the action research has helped the researchers to learn in depth the problems faced by the Inland Revenue Board of Malaysia and taxpayers in identifying the interpretation of section 4A of the Income Tax Act 1967 through the engagements made by the researchers from the focus group discussions and semi-structured interviews. The researchers found that the process of data collection is rather time-consuming and rigour as action research provides a mix of responsiveness and rigour, thus meeting both the action and research requirements (Dick, 2002). By conducting this research, it can be said that action research is an innovative method. Future research should explore the using of action research in making changes to improve the clarity on other critical areas of the ITA.

\section{REFERENCES}

Azman, H. (2014). Strategy by prototyping framework for SMEs through integrating design thinking and balanced scorecard (Doctoral dissertation, Universiti Utara Malaysia).

Dick, B. (2002). Thesis Resource Paper: You Want to do an Action Research Thesis?

Falcao, T., \& Michel, B. (2018). Scope and Interpretation of Article 12A: Assessing the Impact of the New Fees for Technical Services Article. British Tax Review, (4), 422-440.

Finance Bill 2018. (2018). Finance Bill 2018. Retrieved from: www.hasil.my

Gilmore, T., Krantz, J., \& Ramirez, R. (1986). Action Based Modes of Inquiry and the HostResearcher Relationship. Consultation: An International Journal, 5(3), 160-176.

Herr, K., \& Anderson, G. L. (2014). The action research dissertation: A. guide for students and faculty. Sage publications.

Mcleod, S. (2013). Kolb - Learning Styles The Experiential Learning Cycle. 7-15. Available at: http://www.simplypsychology.org/learning-kolb.html

McNiff, J. (2014). Writing and Doing Action Research. 2014. Writing and Doing Action Research. SAGE.

Mee, I. C., \& Hilman, H. (2015). A Visual Framework for Identifying Sources of Unnecessary Regulatory Burdens on Business. Advances In Global Business Research, 12(1), 878.

Multinational tax and transfer pricing news. 2018. "UN Releases Updated Model Tax Treaty Adding New Technical Service Fees Article.” https://Mnetax.Com/Un-Releases-Updated-ModelTax-Treaty-Adding-New-Technical-Service-Fees-Article-27765. 
Nordness, K. L. (2003). Evaluating Levels of Data Quality from Surveys and Focus Groups O'Brien, R. (1998). An Overview of the Methodological Approach of Action Research.

Onwuegbuzie, A. J., Dickinson, W. B., Leech, N. L., \& Zoran, A. G. (2009). A Qualitative Framework for Collecting and Analyzing Data in Focus Group Research. International Journal of Qualitative Methods, 8(3), 1-21.

Saad, N., Udin, N. M., \& Derashid, C. (2014). Complexity of the Malaysian income tax act 1967: Readability assessment. Procedia-Social and Behavioral Sciences, 164, 606-612.

Selener, J. D. (1993). Participatory Action Research and Social Change: Approaches and Critique. Subramaniam, A. (2014). Alam Maritim's Case - Scope and Limitations. MLJ 3:vii.

Susman, G. I. (1983). Action research: a sociotechnical systems perspective. Beyond method: Strategies for Social Research, 95, 113.

Zuber-Skerritt, O., \& Perry, C. (2002). Action research within organisations and university thesis writing. The learning organization, 9(4), 171-179. 